Zeszyty Naukowe Szkoły Głównej Gospodarstwa Wiejskiego

Ekonomika i Organizacja Gospodarki Żywnościowej nr 118, 2017: 127-138

DOI 10.22630/EIOGZ.2017.118.21

Magdalena Gantner, Klaudia Kopczyńska, Katarzyna Król

Katedra Techniki i Projektowania Żywności

Szkoła Główna Gospodarstwa Wiejskiego w Warszawie

Eugenia Czernyszewicz

Katedra Zarządzania i Marketingu

Uniwersytet Przyrodniczy w Lublinie

\title{
Konkurencyjność polskich odmian orzechów laskowych w zależności od ich jakości określonej właściwościami fizykochemicznymi
}

\section{Wstęp}

Wysoka jakość produktów żywnościowych stanowi jeden z ważniejszych czynników determinujących poziom konkurencyjności przemysłu spożywczego. Jest ona osiagana głównie dzięki podejmowaniu działań innowacyjnych z zastosowaniem nowości technologicznych. W ujęciu ekonomicznym jakość ,,jest to stopień zgodności produktu z wymaganiami odbiorcy, a te z kolei wynikają z jego potrzeb, dochodów i cen" [Oyrzanowski 1969]. Z punktu widzenia konsumenta i producenta jakość odzwierciedla „zdolność produktu do zaspokajania ludzkich potrzeb" [Kraszewski 2005]. Dla konsumenta ważne będzie zaspokojenie swoich potrzeb funkcjonalnych (komfort użytkowania, niezawodność, ekonomiczność) i niefunkcjonalnych (budowanie wizerunku, zaspokojenie potrzeb estetycznych), a według wymagań producenta produkt powinien być konkurencyjny, zyskowny oraz zaspokajać potrzebę technologiczności.

Konkurencja jest zjawiskiem, „którego uczestnicy rywalizują między sobą w dążeniach do analogicznych celów". Konkurencyjność należy rozumieć jako cechę podmiotów działających w warunkach konkurencji [Stankiewicz 2005]. $\mathrm{Na}$ wielu rynkach konkurencja toczy się o szeroko rozumiane zasoby. Aby mogły one stanowić przedmiot konkurencji, muszą mieć charakter dóbr rzadkich, przy czym rzadkość można rozumieć zarówno w ujęciu ilościowym, jak i jakościowym. Wymiar ilościowy zasobów w połączeniu z cechami jakościowymi 
może wpłynąc decydująco na ich rzadki charakter, a tym samym na możliwości konkurencyjne podmiotów, które takie zasoby posiadają. Można więc stwierdzić, że konkurencyjność jest cechą podmiotów, które posiadają zdolność do wytwarzania dóbr rzadkich akceptowanych na rynku. Stopień akceptacji dóbr jest uzależniony od postrzegania ich wartości użytkowej, na którą wpływ mają głównie cechy jakościowe. Z tego względu w artykule przeanalizowano cechy jakościowe orzechów laskowych uprawianych na terytorium Polski pod względem cech technologicznych predysponujących ten produkt dla przemysłu. Celem pracy jest porównanie jakości orzechów laskowych uprawianych w Polsce z jakością orzechów importowanych. Analizę przeprowadzono na podstawie oceny zmian ich właściwości fizykochemicznych w zależności od zastosowanych parametrów prażenia.

\section{Produkcja i obrót orzechami laskowymi w Polsce i na świecie}

Uprawa leszczyny jako źródła owoców będących zarówno cennym surowcem dla przemysłu żywnościowego, jak i przeznaczonych do bezpośredniej konsumpcji stanowi ważny kierunek rozwoju produkcji ogrodniczej w wielu krajach. Światowy areał uprawy leszczyny wynosi 915,55 tys. ha, z czego ponad 3/4 powierzchni znajduje się na terenie Turcji [FAOSTAT 2017]. Ocenia się, że w Polsce towarowe plantacje leszczyny (powyżej 1 ha) zajmują obecnie ponad 4,02 tys. ha. Produkcja na poziomie 5,53 tys. t plasuje obecnie Polskę na 10. miejscu wśród światowych producentów. W 2014 roku zbiory orzechów laskowych na świecie wyniosły 713,45 tys. t, z czego najwięcej pozyskano w Turcji (63\% światowej produkcji), następnie we Włoszech (11\%), Gruzji (5\%), Stanach Zjednoczonych (5\%), Azerbejdżanie (4\%), Chinach (3\%), Iranie (3\%), Hiszpanii (2\%), we Francji (2\%) i w Polsce (1\%) [FAOSTAT 2017].

Uprawa leszczyny w Polsce w latach 2004-2011 była objęta finansowym wsparciem $w$ ramach UE. W tym czasie areał upraw powiększył się ponad dwukrotnie, z 1,65 tys. do 3,49 tys. ha [FAMU/FAPA 2017]. Do 2014 roku powierzchnia upraw uległa dalszemu zwiększeniu o ponad 2 tys. ha. Czynnikiem, który miał niewątpliwy wpływ na opłacalność uprawy leszczyny w Polsce (poza wsparciem unijnym), jest plonowanie na średnim poziomie $1,7 \mathrm{t} / \mathrm{ha}$, co jest porównywalne z wydajnością plantacji włoskich czy hiszpańskich i znacznie przewyższa przeciętne plony uzyskiwane w Turcji, które wynoszą 0,9 t/ha [Gantner 2009]. Obserwacje plonowania towarowych plantacji leszczyny oraz analiza 
kosztów produkcji, a także opinie producentów orzechów laskowych, pozwoliły już w 2004 roku na stwierdzenie, że produkcja ta jest opłacalna i może być istotnym źródłem dodatkowych dochodów w gospodarstwach sadowniczych lub rolnych [Czernyszewicz i Kolano 2004]. Wsparcie unijne po 2004 roku zwiększyło opłacalność i zmniejszyło ryzyko finansowe prowadzenia tego typu produkcji sadowniczej w Polsce.

Ważną determinantą rozwoju produkcji orzechów laskowych jest to, że zdecydowana większość tego surowca na rynku unijnym kierowana jest do przetwórstwa. Tylko 15 tys. przeznacza się do bezpośredniej konsumpcji, co w zupełności zaspokaja potrzeby rynku. Największym światowym importerem orzechów laskowych są Niemcy, a około $80 \%$ całej światowej produkcji trafia do Europy [Gönenç i in. 2006]. Podaż orzechów zapewniana przez producentów unijnych, przy produkcji na poziomie 144,91 tys. ton orzechów w łupinach, nie jest $\mathrm{w}$ stanie zaspokoić popytu na ten surowiec w krajach UE. Import z krajów trzecich wyniósł w 2013 roku ponad 165 tys. t orzechów łuskanych i pochodził w zdecydowanej większości z Turcji (ponad 80\%). Poza tym orzechy są kupowane w Gruzji, Azerbejdżanie oraz Chile. Unijny eksport tego surowca jest na niskim poziomie i w 2013 roku wyniósł 31,72 tys. t orzechów łuskanych. Biorąc pod uwagę możliwe zmiany w sytuacji społeczno-gospodarczej Turcji, głównego producenta tego surowca, związane ze zmianami politycznymi i możliwością ograniczeń w handlu z UE oraz to, że import orzechów laskowych z krajów trzecich przewyższa zdecydowanie obecną produkcję w krajach UE, należy uznać produkcję orzechów laskowych w Polsce za jeden z bardziej perspektywicznych kierunków rozwoju produkcji sadowniczej. Sukces polskich producentów uzależniony jest jednak od uznania polskich odmian orzechów laskowych za spełniające wymogi przemysłu żywnościowego, zarówno pod względem technologicznym, jak i żywieniowym. Rozwój tego sektora będzie zatem możliwy wyłącznie poprzez znaczące zwiększenie popytu na orzechy laskowe produkowane w krajach UE przez branżę przetwórstwa żywności w stosunku do konsumpcji indywidualnej [FAMMU/FAPA 2017, FAOSTAT 2017].

Polska jest zmuszona corocznie importować orzechy laskowe, a rodzimy surowiec przeznaczony jest wyłącznie do bezpośredniej konsumpcji. Skala importu orzechów laskowych jest zatem nieporównywalnie większa od eksportu. Po akcesji Polski do UE krajowy import orzechów łuskanych wzrósł z 5,23 tys. $\mathrm{t}$ w 2004 roku do 7,55 tys. t w 2007 roku. W tym przypadku surowiec głównie był przeznaczany do produkcji wszelkiego rodzaju słodyczy. W kolejnych latach zaznaczył się nagły jego spadek do 2,38 tys. t w 2013 roku. Wolumen eksportu orzechów laskowych z Polski jest niski, osiagając w 2013 roku zaledwie 173 t [FAOSTAT 2017]. 


\section{Materiał, metody badań}

Materiałem badawczym były orzechy dwóch odmian leszczyny uprawianej w Polsce: 'Olbrzym z Halle' i 'Cosford', które zebrano we wrześniu 2016 roku na plantacji należącej do Wojewódzkiego Ośrodka Doradztwa Rolniczego w Końskowoli (woj. lubelskie, $51^{\circ} 25^{\prime} \mathrm{N} 22^{\circ} 03^{\prime} \mathrm{E}$ ). Wyselekcjonowane orzechy w łupinie o średnicy powyżej $16 \mathrm{~mm}$, spełniające wymagania dotyczące klasy „Ekstra” zgodnie z wymogami zawartymi w rozporządzeniu Komisji (WE) $1284 / 2002$, pozbawiono łupiny i poddano procesowi prażenia.

Prażenie przeprowadzono w komorowej suszarce konwekcyjnej Binder Model FD115 przy stałej prędkości przepływu powietrza. Zastosowano dziewięć kombinacji temperaturowo-czasowych $\left(3\right.$ temperatury razy 3 czasy): $110^{\circ} \mathrm{C}$ przez 15,30 i $60 \mathrm{~min}, 130^{\circ} \mathrm{C}$ przez 15,30 i $60 \mathrm{~min}$ oraz $160^{\circ} \mathrm{C}$ przez 15,30 i $60 \mathrm{~min}$. W każdej kombinacji uwzględniono po $100 \mathrm{~g}$ orzechów badanych odmian.

W orzechach surowych i prażonych oznaczono: aktywność wody, barwę powierzchni łuski wewnętrznej (brązowej) i powierzchni czystego jądra orzecha oraz jego twardość. Aktywność wody zmierzono w trzech powtórzeniach za pomocą higrometru Aqualab ${ }^{\circledR} 3$ TEV (Decagon Devices Inc., Pullman, WA., USA). Instrumentalny pomiar barwy orzechów laskowych wykonano w systemie przestrzeni barw CIE L*a*b* przy użyciu aparatu Konica Minolta model CR-400 (CR-400, Konica Minolta Inc., Tokyo, Japan). Określenie parametrów barwy przeprowadzono losowo na 10 próbach orzechów przed prażeniem i po nim oraz po ręcznym usunięciu łuski okrywającej jądra orzechów. Na podstawie uzyskanych wyników obliczono indeks brązowienia (BI - ang. browning index), używając następującego równania [Mexis i Kontominas 2010]:

$$
\mathrm{BI}=\frac{[100(\mathrm{x}-0,31)]}{0,17}
$$

gdzie:

$x=\frac{(a+1,75 L)}{5,64 L+a-3,012 b)}$

Do pomiaru właściwości teksturalnych orzechów laskowych użyto Uniwersalnej Maszyny Testującej firmy Instron z głowicą w zakresie pomiarowym do $500 \mathrm{~N}$ (model 5965, Instron, Kanton, USA). Wykonano test pojedynczego ściskania przy prędkości przesuwu głowicy pomiarowej $10 \mathrm{~mm} / \mathrm{min}$, w sześciu powtórzeniach dla każdej kombinacji temperaturowo-czasowej. Jądro orzecha ściskano do 50\% jego wysokości. Wyniki testów analizowano za pomocą komputera z oprogramowaniem Bluehill@2. 
Do statystycznego opracowania danych, oceny różnic między wynikami wykorzystano jednoczynnikową analizę wariancji ANOVA przy użyciu programu Statistica 12.0. Istotność przyjęto na poziomie $\mathrm{p} \leq 0,05$.

\section{Wyniki i dyskusja}

Orzechy przed prażeniem charakteryzowały się aktywnością wody na poziomie 0,28 (rys. 1). Dla wszystkich zastosowanych parametrów temperatury i czasu prażenia stwierdzono znaczny spadek aktywności wody, porównywalny dla orzechów obu odmian. Najmniejszą aktywność wody (na poziomie 0,07 ) uzyskano dla orzechów prażonych w temperaturze $130^{\circ} \mathrm{C}$ przez 60 min. Końcowa zawartość wody w orzechach prażonych w temperaturze $110,130 \mathrm{i} 160^{\circ} \mathrm{C}$ przez 30 min wyniosła dla odmiany 'Olbrzym z Halle'- 0,20; 0,10 i 0,08, a dla odmiany 'Cosford' - 0,21; 0,08 i 0,06. Dla orzechów każdej odmiany spadek aktywności wody był zbliżony, a różnice między odmianami nie były istotne statystycznie. Wyniki uzyskanych analiz są porównywalne z badaniami przeprowadzonymi na innych orzechach laskowych [Maskan 2001, Kulik i Waszkiewicz-Robak 2015]. Zawartość wody pełni kluczową rolę w zapewnieniu odpowiednich warunków do wzrostu i rozwoju mikroflory zanieczyszczającej żywność. Trwałość produktów spożywczych, których aktywność wody na poziomie poniżej 0,65 , wynosi zazwyczaj więcej niż pół roku [Ćwiertniewski i in. 2005, Guine i in. 2015]. Prażenie stanowi ochronę nie tylko przed rozwojem mykotoksyn, ale także jełczeniem frakcji tłuszczowej orzecha [Amaral i in. 2006, Ciemniewska-Żytkiewicz i in. 2015, Moghaddam i in. 2016].

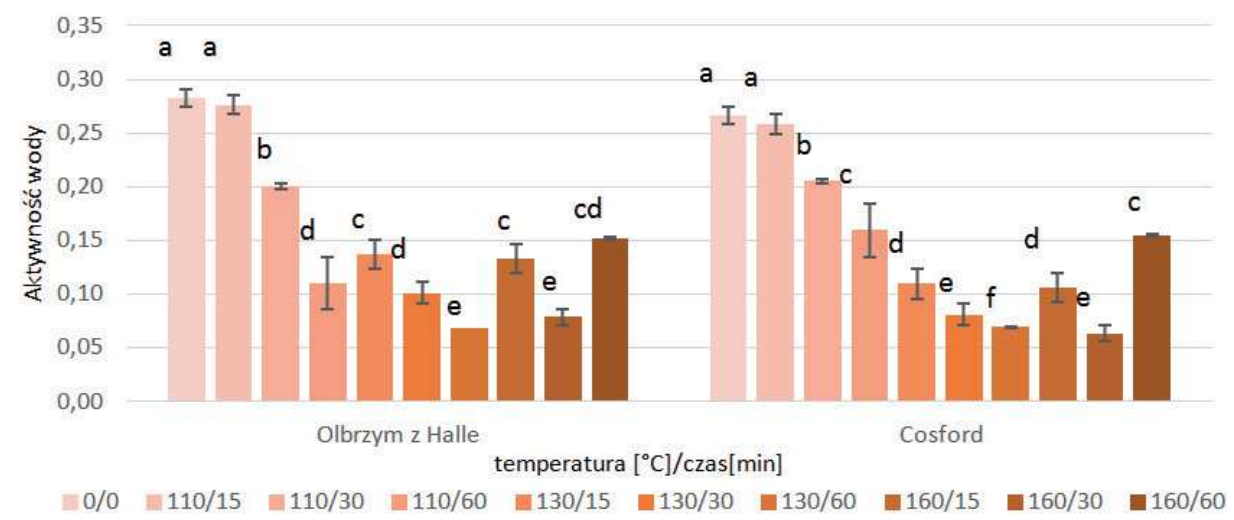

\section{Rysunek 1}

Zmiany aktywności wody w orzechach laskowych odmian 'Olbrzym z Halle' i 'Cosford' w zależności od zastosowanych parametrów prażenia. Wartości oznaczone tą samą literą nie różnia się istotnie statystycznie przy $p \leq 0,05$

Źródło: Opracowanie własne. 


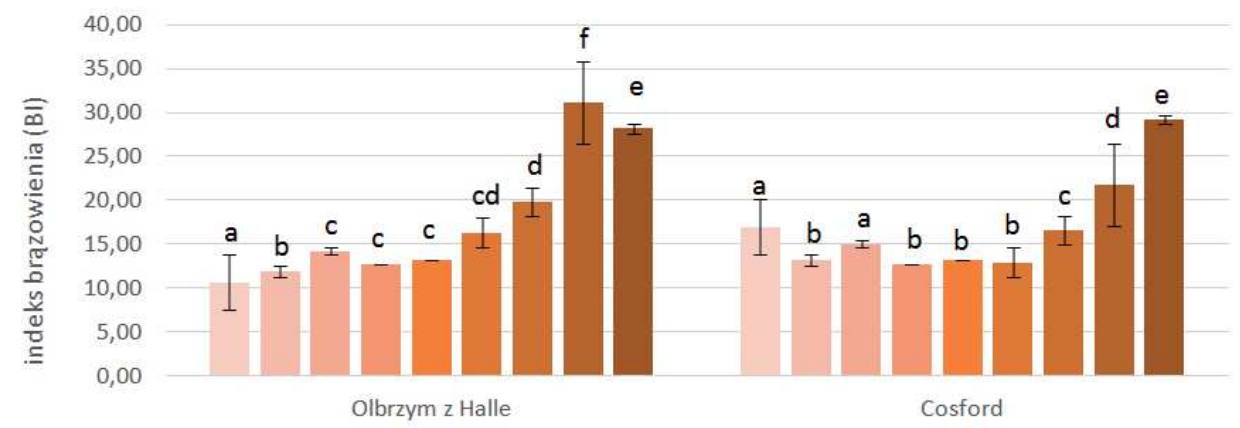

temperatura $\left[{ }^{\circ} \mathrm{C}\right] / \operatorname{czas}[\mathrm{min}]$

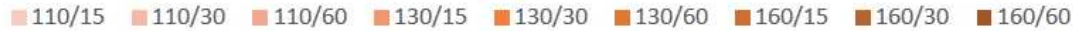

\section{Rysunek 2}

Zmiany wartości indeksu brązowienia (BI) orzechów laskowych odmian 'Olbrzym z Halle' i 'Cosford' w zależności od zastosowanych parametrów prażenia. Wartości oznaczone tą samą literą nie różnią się istotnie statystycznie przy $p \leq 0.05$

Żródło: Opracowanie własne.

A
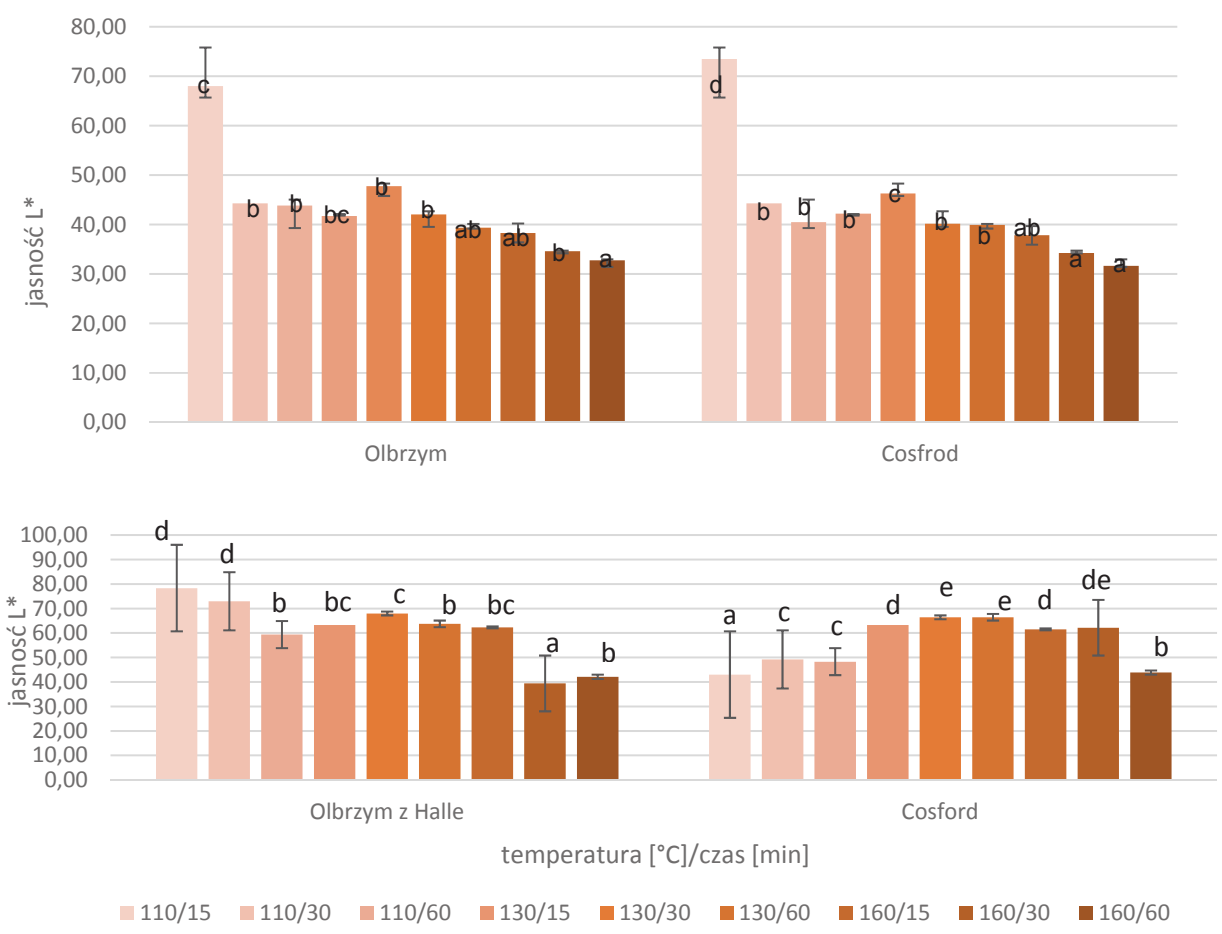

\section{Rysunek 3}

Zmiany jasności jąder orzechów odmian 'Olbrzym z Halle' i 'Cosford' w skórce (A) oraz obranych (B) w zależności od zastosowanych parametrów prażenia. Wartości oznaczone tą samą litera nie różnią się istotnie statystycznie przy $p \leq 0.05$.

Źródło: Opracowanie własne. 
Proces prażenia wpłynął istotnie na barwę zarówno orzechów prażonych w łusce wewnętrznej, jak i jej pozbawionych (rys. 2 i 3). Wraz ze zwiększeniem temperatury prażenia, niezależnie od odmiany, zaobserwowano pociemnienie barwy. Jasność $\left(\mathrm{L}^{*}\right)$ orzechów odmiany 'Olbrzym z Halle' w brązowej łusce zmniejszyła się istotnie pod wpływem prażenia we wszystkich zastosowanych zakresach czasu i temperatury, z wyjątkiem wariantu $130^{\circ} \mathrm{C} / 15$ min. Jasność orzechów tej odmiany pozbawionych zewnętrznej łuski zmniejszyła się istotnie po prażeniu we wszystkich zakresach temperatury i czasu, z wyjątkiem wariantu $110^{\circ} \mathrm{C} / 30 \mathrm{~min}$. Wartość parametru jasności ( $\left.\mathrm{L}^{*}\right)$ orzechów odmiany 'Cosford' zarówno tych w brązowej łusce, jak i jej pozbawionych zmniejszyła się istotnie w przypadku każdej z zastosowanych kombinacji.

Dodatkowo wyznaczono wartość indeksu brązowienia (BI), który był wykorzystywany $\mathrm{w}$ innych badaniach na różnych rodzajach orzechów [Ozdemir i Akinci 2004, Febrianto i in. 2016]. Parametr ten jest istotną miarą intensywności barwy brązowej, wynikającej z reakcji nieenzymatycznego brązowienia [Mohammadi 2008]. W przeprowadzonym doświadczeniu zaobserwowano, że wraz ze zwiększeniem temperatury prażenia i wydłużeniem procesu we wszystkich analizowanych próbach nastąpiło pociemnienie barwy i wzrost wartości indeksu brązowienia. Zmiany te były wynikiem reakcji Maillarda, w których szybkość tworzenia związków barwnych zwiększa się wraz ze wzrostem temperatury i prowadzi do powstania związków odpowiedzialnych za smak, zapach oraz atrakcyjność produktów spożywczych [Michalska i Zieliński 2007].

Analizując uzyskane wyniki, należy stwierdzić, że jądra prażonych orzechów laskowych, niezależnie od odmiany, wraz ze wzrostem temperatury prażenia charakteryzowały się obniżeniem jasności ( $\left.\mathrm{L}^{*}\right)$ i wzrostem indeksu brązowienia (BI), co potwierdzają badania przeprowadzone przez Donno i innych [2013]. Zastosowane prażenia przyczyniło się również do tego, że brązowa łuska zewnętrzna orzecha łatwiej odchodziła od jądra. Orzechy obu odmian po prażeniu w temperaturze $130^{\circ} \mathrm{C}$ przez 30 min charakteryzowały się porównywalną, dużą łatwością usuwania brązowej łuski wewnętrznej.

W badanych surowych i prażonych orzechach laskowych dwóch odmian określono teksturę, wyznaczając maksymalną siłę ściskającą, przy której następuje zniszczenie struktury. Analizując otrzymane wyniki (rys. 4) stwierdzono, że wraz z rosnącą temperaturą prażenia i upływem czasu procesu prażenia twardość jąder orzechów laskowych ulegała obniżeniu od 115,9 $\mathrm{N} \mathrm{w}$ orzechach surowych do $23,6 \mathrm{~N}$ w orzechach prażonym w temperaturze $160^{\circ} \mathrm{C}$ przez $30 \mathrm{~min}$ ('Olbrzym z Halle') oraz od 212,9 do 20,9 N ('Cosford'). Wraz z intensywnym odparowywaniem wody pod wpływem wzrastającej temperatury, orzechy stawały się coraz bardziej kruche. Stwierdzone różnice odmianowe w badanych parametrach wynikały z wielkości orzechów laskowych i wielkości wolnej przestrzeni, 


\section{4}

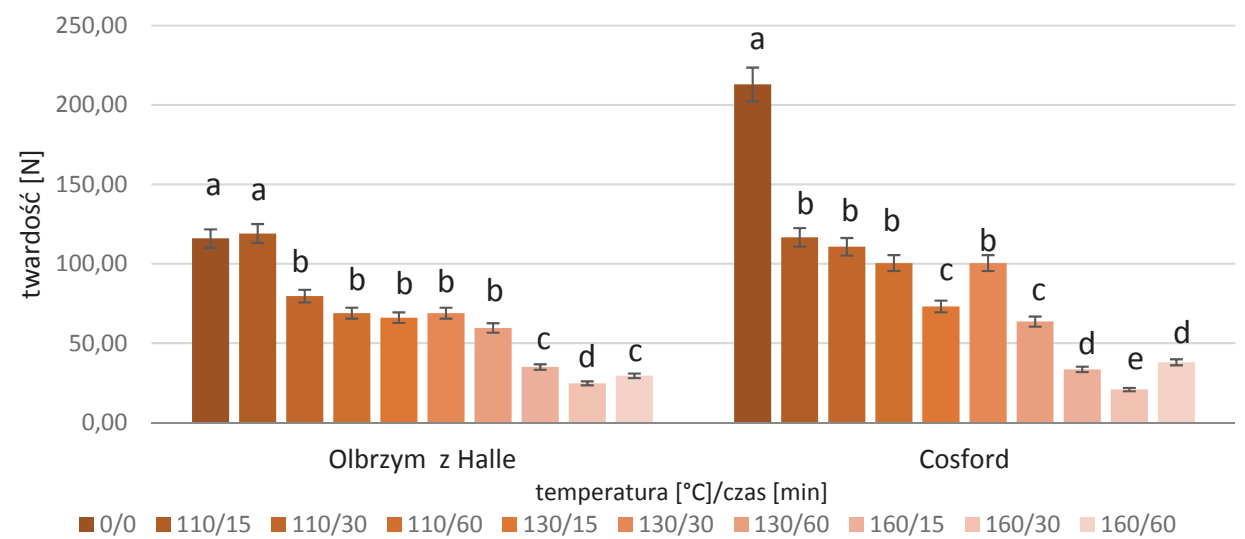

\section{Rysunek 4}

Zmiany twardości jąder orzechów laskowych odmian 'Olbrzym z Halle' i 'Cosford' w zależności od zastosowanych parametrów prażenia. Wartości oznaczone tą samą literą nie różnią się istotnie statystycznie przy $p \leq 0.05$.

Źródło: Opracowanie własne.

obecnej w centrum jądra orzecha. Orzechy odmiany 'Cosford' charakteryzowały się większą twardością $(212,9 \mathrm{~N})$ w stanie surowym w porównaniu do orzechów odmiany 'Olbrzym z Halle' (115,9 N). W badaniach przeprowadzonych przez Giacosa i innych [2016] na orzechach laskowych odmian tureckich, odnotowano mniejszą twardość $(97,2 \mathrm{~N})$ surowych orzechów, ale większą uzyskano po prażeniu $\mathrm{w}$ temperaturze $160^{\circ} \mathrm{C}$ przez $30 \min (85,1 \mathrm{~N}) \mathrm{w}$ porównaniu do orzechów odmian polskich. Ozdemir i Akinci [2004] podaja, że twardość surowych orzechów laskowych odmian tureckich oscylowała w granicach od 50 do 64 N. Według Belviso i innych [2017], twardość surowych orzechów odmian włoskich wahała się od 93,2 do 96,4 N, a po prażeniu spadła do wartości od 57,7 do $83,4 \mathrm{~N}$. W badaniach własnych wykazano, że temperatura procesu ma większy wpływ na teksturę orzechów niż czas obróbki termicznej. Również Kita i Figiel [2010] stwierdzili, że orzechy włoskie prażone $\mathrm{w} 100^{\circ} \mathrm{C}$ przez 17 min charakteryzowały się większą twardością w porównaniu z orzechami prażonymi w wyższej temperaturze, w tym samym czasie.

\section{Podsumowanie i wnioski}

Właściwości fizykochemiczne orzechów laskowych są częstym tematem analiz w aspekcie ich jakości, ale dotyczą one głównie orzechów laskowych odmian zagranicznych. Przywołane w niniejszym opracowaniu wyniki badań własnych dowodzą że zmiany tych właściwości są porównywalne do wyników 
uzyskanych na odmianach zagranicznych. Orzechy laskowe polskiej produkcji charakteryzują się równie dobrymi parametrami fizykochemicznymi jak odmiany zagraniczne, co czyni je konkurencyjnymi na globalnym rynku. W związku z tym możliwe jest wytypowanie odmian polskich o wysokiej jakości przetwórczej oraz przydzielenie ich do konkretnych branż przemysłu spożywczego. Za niezbędne zatem z punktu widzenia rozwoju polskiej produkcji orzechów laskowych, należy uznać dalsze prowadzenie badań właściwości fizykochemicznych orzechów laskowych odmian polskich, tak aby zwiększyć wykorzystanie tego surowca w produkcji krajowej i unijnej.

W kontekście przywołanych wyników badań należy podkreślić, że prażenie orzechów ma istotny wpływ na poprawę ich właściwości technologicznych. Proces prażenia powoduje obniżenie aktywności wody, zmniejszenie jasności (L*) jąder orzechów laskowych, niezależnie od odmiany, i wzrost wartości indeksu brązowienia, a głównym parametrem decydującym o tych zmianach jest temperatura. Ponadto wraz ze zwiększaniem się temperatury procesu, twardość orzechów zmniejsza się, a ich tekstura staje się bardziej krucha. Orzechy odmiany 'Cosford' charakteryzowały się większą twardością w stanie surowym od orzechów odmiany 'Olbrzym z Halle'. Najlepszą jakość orzechów poddanych prażeniu, niezależnie od odmiany, zapewniała temperatura $130^{\circ} \mathrm{C} \mathrm{w}$ czasie $30 \mathrm{~min}$. Orzechy obu odmian poddane prażeniu w tych parametrach charakteryzowały się porównywalną, większą łatwością w usuwaniu brązowej łuski wewnętrznej.

Tym samym należy stwierdzić, że dobór optymalnych parametrów procesów technologicznych podczas prażenia może wpłynąc na wzrost jakości przetwórczej orzechów laskowych polskiej produkcji, co w konsekwencji umożliwi uzyskanie konkurencyjności względem odmian zagranicznych i zwiększy szansę ich eksportowania, a także wykorzystania w krajowej produkcji cukierniczej.

\section{Literatura}

AMARAL J.S., CASAL S., SEABRA R.M., OLIVEIRA B.P., 2006: Effects of roasting on hazelnut lipids, Journal of Agricultural and Food Chemistry 54, 1315-1321.

BELVISO S., BELLO DAL B., GIACOS S., BERTOLINO M., CHIRARDELLO D., GIORDANO M., ROLLE L., GERBI V., ZEPPA G., 2017: Chemical, mechanical and sensory monitoring of hot air-and infrared roasted hazelnuts (Corylus avellana L.) during nine months of storage, Food Chemistry 217, 398-408.

CIEMNIEWSKA-ŻYTKIEWICZ H., VERARDO V., PASINI F., BRYŚ J., KOCZOŃ P., CABONI M.F., 2015: Determination of lipid and phenolic fraction in two hazelnuts (Corylus avellana L.) cultivars grown in Poland, Food Chemistry 168, 615-622.

CZERNYSZEWICZ E., KOLANO A., 2004: Leszczyna źródtem dodatkowych dochodów, Hasło Ogrodnicze 6, 7. 
ĆWIERTNIEWSKI K., POLAK E., EGIERSKI K., 2005: Aktywność wody-parametr trwatości produktów spożywczych, Przemysł Spożywczy 5, 16-19.

DONNOD.,BECCAROG.L.,MELLANOG.M.,PRIMAS.,CAVICHIOLIM.,CERUTTIA.K., BOUNOUS G., 2013: Setting a protocol for hazelnut rostint using sensory and colormetric analysis: Influence of the roasting temperature on the quality of Tonda Gentile delle Lange cv. hazelnut, Czech Journal of Food Science 31, 390-400.

FAMMU/FAPA, 2017: Dane handlu zagranicznego artykułami rolno-spożywczymi w 2017 roku.

FAOSTAT, 2017: Food and Agriculture Organization of the United Nations, http://www.fao. org/faostat/en/\#home.

FEBRIANTO N.A., YANG T.A., Wan ABDULLAH W.A., 2016: Cocoa-like flavor compound development of rambutan seed fat as the effect of fermentation and roasting, International Food Research Journal 23, 2166-2174.

GANTNER M., 2009: Koszty ochrony plantacji leszczyny przed szkodnikami i chorobami, Progress in Plant Protection 49(1), 1610-1616.

GIACOSA S., BELVISO S., BERTOLINO M., DAL BELLO B., GERBI V., GHIRARDELLO D., GIORDANO M., ZEPPA G., ROLLE Z. 2016: Hazelnut kernels (Corylus avellana L.) mechanical and acoustic properties determination: Comparison of test speed, compression or shear axis, roasting, and storage condition effect, Journal of Food Engineering 173, 59-68.

GÖNENÇ S., TANRIVERMI H., BÜLBÜL M., 2006: Economic assessment of hazelnut production and the importance of supply management approaches in Turkey, Journal of Agriculture and Rural Development in the Tropics and Subtropics 107(1), 19-32.

GUINE R.P.F., ALMEIDA C.F.F., CORREIA P.M.R., MENDES M., 2015: Modeling the influence of origin, packing and storage on water activity, colour and texture of almond, hazelnuts and walnuts using artificial neural networks, Food Bioprocess Technology 8, 1113-1125.

KARASZEWSKI R., 2005: Zarzqdzanie jakościq. Koncepcje, metody i narzędzia stosowane przez liderów światowego biznesu, Dom Organizatora 19.

KITA A., FIGIEL A., 2010: Wpływ temperatury prażenia na właściwości nasion stonecznika, Rośliny Oleiste 31, 133-145.

KULIK K., WASZKIEWICZ-ROBAK B., 2015: Orzechy jadalne jako źródto sktadników bioaktywnych, [w:] M. Karwowska, W. Gustaw (red.), Trendy w żywieniu człowieka, Wydawnictwo Naukowe PTTŻ, Kraków, 143-156.

MASKAN M., 2001: Kinetics of colour change of kiwifruits during hot air and microwave drying, Journal of Food Engineering 48, 169-175.

MEXIS S.F., KONTOMINAS M.G., 2010: Effect of oxygen absorber, nitrogen flushing, packaging material oxygen transmission rate and storage conditions on quality retention of raw whole unpeeled almond kernels (Prunus dulcis), LWT - Food Science Technology 43, 1-11.

MICHALSKA A., ZIELIŃSKI H., 2007: Produkty reakcji Maillarda w żywności, Żywność, Nauka. Technologia. Jakość 2(51), 5-16.

MOGHADDAM M.T., RAZAVI M.A.S., TAGHIZADEH M., SAZGARNIA A., 2016: Sensory and instrumental texture assessment of roasted pistachio nut/kernel by partial least square (PLS) regression analysis: effect of roasting conditions, Food Science Technology 53(1), 370-380. 
MOHAMMADI A., TABATABAEEFAR A., SHAHIN S., RAFIEE S., KEYHANI A., 2008: Energy use and economic analysis of potato production in Iran a case study: Ardabil province, Energy Conversion and Management 49, 3566-3570.

OZDEMIR F., AKINCI I., 2004: Physical and nutritional properties of four major commercial Turkish hazelnut varieties, Journal of Food Engineering 63, 341-347.

OYRZANOWSKI B., 1969: Ekonomiczne problemy jakości, Ekonomista 2, 586-597.

Rozporządzenie Komisji (WE) nr 1284/2002 Parlamentu Europejskiego i Rady z dnia 15 lipca 2002 r. ustanawiające normę handlową w odniesieniu do orzechów laskowych w łupinach, Dz.U. L 187/14.

STANKIEWICZ M.J., 2005: Konkurencyjność przedsiębiorstwa. Budowanie konkurencyjności przedsiębiorstwa w warunkach globalizacji, Dom Organizatora, Toruń.

\section{Abstrakt}

Celem pracy jest porównanie jakości orzechów laskowych uprawianych w Polsce do orzechów importowanych, dokonane na podstawie oceny zmian ich właściwości fizykochemicznych w zależności od zastosowanych parametrów prażenia. Materiałem badawczym były orzechy dwóch odmian leszczyny uprawianej w Polsce: 'Olbrzym z Halle' i 'Cosford'. Próbki poddano obróbce cieplnej w dziewięciu kombinacjach: w temperaturze $110^{\circ} \mathrm{C}, 130^{\circ} \mathrm{C}$ i $160^{\circ} \mathrm{C}$, każda w czasie 15, 30 i 60 min. Badano takie parametry, jak: aktywność wody, barwa powierzchni łuski wewnętrznej (brązowej) i powierzchni czystego jądra orzecha oraz jego twardość. Proces prażenia spowodował obniżenie aktywności wody, zmniejszenie jasności ( $\left.\mathrm{L}^{*}\right)$ jąder orzechów laskowych niezależnie od odmiany i wzrost wartości indeksu brązowienia (BI). Głównym parametrem decydującym o tych zmianach była temperatura. Ponadto, wraz ze zwiększaniem się temperatury procesu, twardość orzechów zmniejszała się, a ich struktura stawała się bardziej krucha i delikatna. Orzechy odmiany 'Cosford' charakteryzowały się większą twardością w stanie surowym w porównaniu do orzechów odmiany 'Olbrzym z Halle’. Najwyższą jakość orzechów niezależnie od odmiany zapewniało prażenie $\mathrm{w} 130^{\circ} \mathrm{C}$ przez $30 \mathrm{~min}$. Orzechy obu odmian prażone w tych parametrach charakteryzowały się porównywalną, dużą łatwością w usuwaniu z nich brązowej łuski wewnętrznej.

Dobór optymalnych parametrów procesów technologicznych może wpłynąć na poprawę właściwości przetwórczych orzechów laskowych uprawianych w Polsce, co w konsekwencji umożliwi osiagnięcie konkurencyjności względem zagranicznych odmian i zwiększy szansę ich eksportu, a także wykorzystanie ich krajowej produkcji cukierniczej.

Słowa kluczowe: orzechy laskowe, konkurencyjność, jakość, prażenie, aktywność wody, tekstura, barwa 


\title{
Competitiveness of Polish cultivars of hazelnuts depending on their quality determined by physicochemical properties
}

\begin{abstract}
The aim of the study is to compare the quality of hazelnuts grown in Poland in opposition to imported ones, based on their changes in physicochemical properties depending on the roasting parameters. The plant material was two hazelnuts cultivars grown in Poland: 'Olbrzym z Halle' and 'Cosford'. The samples were roasted at nine specific temperatures and time conditions: at $110^{\circ} \mathrm{C}, 130^{\circ} \mathrm{C}$ and $160^{\circ} \mathrm{C}$, each at 15,30 and $60 \mathrm{~min}$. Parameters such as water activity, color of the inner (brown) skin of the husk and color of the pure kernel's surface and hardness were investigated.

The roasting process reduced water activity, decreased luminosity $\left(\mathrm{L}^{*}\right)$ of kernel hazelnuts irrespective of cultivar and increased browning index (BI) value. The main parameter determining these changes was temperature. In addition, as the process temperature increased the hardness of the nuts and their structure became more fragile and delicate. Nuts of 'Cosford' cultivar were characterized by higher hardness compared to the nuts of 'Olbrzym z Halle' cultivar. The temperature of $130^{\circ}$ for 30 min provided the best quality of the roasted nuts, regardless of the cultivar. Nuts of both cultivars, roasted in these parameters were characterized by comparable, high ease of removal of the brown inner skin.

The selection of optimal parameters of technological process can improve the processing properties of Polish hazelnuts and, consequently, ensure their competitive advantage against nuts grown in other countries. This fact could increase both the chance of their export as well as the use in Polish confectionery production.
\end{abstract}

Key words: hazelnuts, competitiveness, quality, roasting, water activity, texture, color 